\title{
COVID-19 Outbreak and Perspective in Morocco
}

\author{
Rachid Ait Addi ${ }^{1 \star}$, Abdelhafid Benksim ${ }^{1,2}$, Mohamed Amine ${ }^{3}$, Mohamed Cherkaoui ${ }^{1}$
}

\author{
${ }^{1}$ Laboratory of Human Ecology, Department of Biology, School of Sciences Semlalia, Cadi Ayyad University, Marrakesh. MOROCCO \\ ${ }^{2}$ High Institute of Nursing and Technical Health, Marrakesh, MOROCCO \\ ${ }^{3}$ Laboratory of Epidemiology, School of Medicine of Marrakesh, MOROCCO \\ *Corresponding Author: dr.rachid.aitaddi@gmail.com
}

Citation: Ait Addi R, Benksim A, Amine M, Cherkaoui M. COVID-19 Outbreak and Perspective in Morocco. Electron J Gen Med. 2020;17(4):em204. https://doi.org/10.29333/ejgm/7857

ARTICLE INFO

Received: 23 Mar. 2020

Accepted: 26 Mar. 2020

\begin{abstract}
Coronavirus disease 2019 (COVID-19) is a respiratory illness that can spread from person to person. The virus that causes COVID-19 is a novel coronavirus that was first identified during an investigation into an outbreak in Wuhan, China and rapidly spread across the world to become the first pandemic caused by a coronavirus.

As of 26 March 2020, there are 275 cases affected by COVID-19 announced by the Moroccan government, and it possible to limit the spread of this serious disease, with the cooperation of all the citizens in respect of the measures of containment and individual protection. Also, with the announce yesterday by the Moroccan government of the authorization of use of chloroquine in treatment of COVID-19 pneumonia, COVID-19 will be soon eradicated from Morocco and hopefully from all over the world
\end{abstract}

Keywords: COVID-19, pandemic, containment, chloroquine, Coronavirus, pneumonia
Coronavirus disease 2019 (COVID-19) is a respiratory illness that can spread from person to person. The virus that causes COVID-19 is a novel coronavirus that was first identified during an investigation into an outbreak in Wuhan, China and rapidly spread across the world to become the first pandemic caused by a coronavirus (1-3).

The virus spreads principally among people who are in contact with each other through respiratory droplets produced when an infected person coughs or sneezes. Also, touching a surface or object that contaminated by the virus, and thereafter touching their own mouth, nose, or eyes can cause COVID-19 infection, but this is not the principal way of the virus spread (4).

Patients with COVID-19 have mild to severe respiratory illness with symptoms of fever, cough and shortness of breath and it is important to note that new data emerges nearly every hour regarding clinical characteristics, treatment options, and outcomes for COVID-19 (5).

The treatment of COVID-19 is initially based on prevention of contamination by containment measures: in China and South Korea, the severe application of such interventions has regularly and drastically reduced new cases, and this experience shows that a reversion of epidemic growth is possible in the short-term (6).

After many studies confirms its ability of reduction of exacerbation of pneumonia, duration of symptoms and delay of viral clearance all in the absence of severe side effects, chloroquine is an efficient treatment regarding the prevention and treatment of COVID-19 pneumonia with the advantage of negligible cost $(7,8)$.
Hydroxychloroquine has probably the same action on viruses as that of chloroquine since the mechanism of action of these two molecules is identical, and hydroxychloroquine can be prescribed for long periods, which would be therefore the first choice in the treatment of COVID-19 (9).

At the moment of a massive increase of cases reported all over the world especially in Italy, France, and Spain, Morocco recorded his first case of COVID-19 in 01 March 2020. Four days after, the second case was detected. After that, from 11 to 13 March a new case was discovered each day. Thereafter, 11 cases were detected each day from 17 to 18 March. Between 18 and 20 March 14 cases were detected each day. Then, 19 cases were detected each day in the period from 20 to 22 March and 28 cases were recorded each day Between 22 and 24 March. Finally, 55 new cases were added from 24 to 25 March (Figure 1).

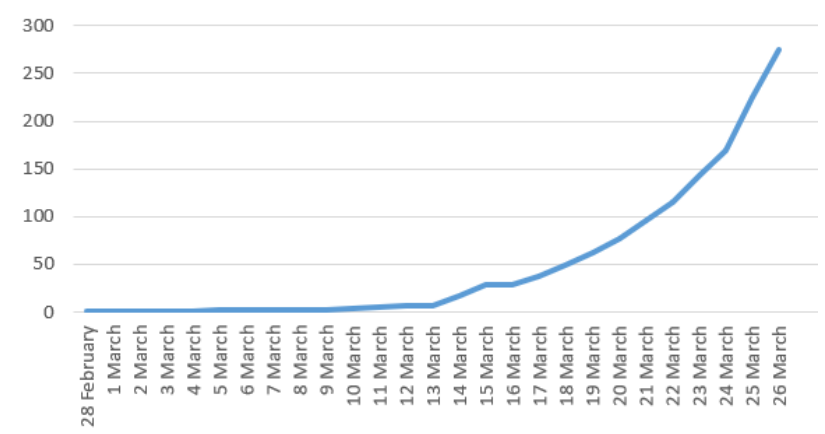

Figure 1. Evolution of COVID-19 cases over time in Morocco (10) 
Moroccan government faced different challenges. In one part, the rapid spread of COVID-19 infection. In other part the difficult task to aware people about the critic situation and at the same time avoid sowing panic and convince people to the idea of containment despite its economic consequences on households. with its experience of containing pandemics especially H1N1 pandemic in 2009, the Moroccan government launched the National monitoring and response plan Coronavirus infection whose objectives are (1) prevent the introduction into the national territory of MERS-CoV; (2) Detect cases early and contain their spread; (3) Organize a national response adapted from the health system; and (4) Strengthen infection prevention and control measures in hospitals (11).

The limitation of people circulating outside their home, social distancing, the cessation of almost all working activities and the request to the population to use protective masks and gloves all have the aim of minimizing the likelihood that people who are not infected come into contact with others who are already infected and probably still asymptomatic (6). In Addition, Moroccan government decided to suspend travel to the countries most affected by the pandemic, and soon after to close the borders. Also, the Moroccan government unlocked a billion dollars to fight COVID-19 and conducted several awareness campaigns to clarify the dangers of COVID-19 and the need of containment and self-protection measures by local officials from door to door, television channels, and social networks. Despite the fact that the majority of Moroccan citizens have respected the instructions of the government, a minority of citizens underestimates the seriousness of the disease and continues to behave as usual. This is often due to low educational level and economic status, and also to cultural factors.

As of 26 March 2020, there are 275 cases affected by COVID19 announced by the Moroccan government, and it possible to limit the spread of this serious disease, with the cooperation of all the citizens in respect of the measures of containment and individual protection. Also, with the announce yesterday by the Moroccan government of the authorization of use of chloroquine in treatment of COVID-19 pneumonia, COVID-19 will be soon eradicated from Morocco and hopefully from all over the world.

\section{ACKNOWLEDGEMENTS}

The authors want to acknowledge the Editorial office of the journal and all the anonymous reviewers. We also thank the Moroccan govenment for all its efforts, and all health care workers whom are on the front lines of the pandemic.

\section{REFERENCES}

1. World Health Organization. Report of the WHO-China Joint Mission on Coronavirus Disease 2019 (COVID-19) Available at: https://www.who.int/docs/default-source/coronavir use/who-china-joint-mission-on-covid-19-final-report.pdf (Accessed 13 March 2020).
2. Li R, Pei S, Chen B, Song Y, Zhang T, Yang W, Shaman J. Substantial undocumented infection facilitates the rapid dissemination of novel coronavirus (SARS-CoV2). Science 2020. https://doi.org/10.1126/science.abb3221 PMid: 32179701

3. Abdulamir AS, Hafidh RR. The Possible Immunological Pathways for the Variable Immunopathogenesis of COVID19 Infections among Healthy Adults, Elderly and Children. Electron J Gen Med. 2020;17(4):em202. https://doi.org/ 10.29333/ejgm/7850

4. Bai Y, Yao L, Wei T, et al. Presumed Asymptomatic Carrier Transmission of COVID-19. JAMA. Published online February 21, 2020. https://doi.org/10.1001/jama.2020.2565 PMid:32083643

5. Li Q, Guan X, Wu P, et al. Early Transmission Dynamics in Wuhan, China, of Novel Coronavirus-Infected Pneumonia. N Engl J Med 2020. https://doi.org/10.1056/NEJMoa2001 316

6. Spagnuolo G, De Vito D, Rengo S, Tatullo, M. COVID-19 Outbreak: An Overview on Dentistry. Int. J. Environ. Res. Public Health 2020;17:2094. https://doi.org/10.3390/ ijerph17062094

7. Gao J, Tian Z, Yang X. Breakthrough: chloroquine phosphate has shown apparent efficacy in treatment of COVID-19 associated pneumonia in clinical studies. Biosci Trends 2020 Feb 19. https://doi.org/10.5582/bst.2020. 01047 PMid:32074550

8. Chinese Clinical Trial Registry. Available at: http://www.chictr.org.cn/searchproj.aspx?title=\%E6\%B0 \%AF\%E5\%96\%B9\&officialname=\&subjectid=\&secondaryi $\mathrm{d}=$ \&applier=\&studyleader=\&ethicalcommitteesanction=\&s ponsor $=\&$ studyailment $=\&$ studyailmentcode $=\&$ studytype $=$ $0 \&$ studystage $=0 \&$ studydesign $=0$ \&minstudyexecutetime $=\&$ maxstudyexecutetime $=\&$ recruitmentstatus $=0$ \&gender $=0$ \& agreetosign $=\&$ secsponsor $=\&$ regno $=\&$ regstatus $=0 \&$ country $=\&$ province $=\&$ city $=\&$ institution $=\&$ institutionlevel=\&measu re $=\&$ intercode $=\&$ sourceofspends $=\&$ createyear $=0$ \&isuploa $\mathrm{drf}=\&$ whetherpublic $=\& b$ tngo=btn\&verifycode $=$ \&page $=1$

9. Colson P, Rolain JM, Lagier JC, Brouqui P, Raoult D. Chloroquine and hydroxychloroquine as available weapons to fight COVID-19, International Journal of Antimicrobial Agents (2020). https://doi.org/10.1016/ j.ijantimicag.2020.105932 PMid:32145363

10. Johns Hopkins University \& Medicine CoronavirusResource Center. Available at: https://coronavirus.jhu.edu/ map.html

11. Plan national de veille et de riposte à l'infection par le Coronavirus 2019-nCoV (Version du 27 Janvier/2020). Available at: https://www.sante.gov.ma/Documents/ 2020/coronavirus/Plan\%20national\%20de\%20veille\%20et \%20de\%20riposte $\% 20 \%$ C3\%A0\%20l\%27infection\%20par $\% 201$ \%20Coronavirus\%202019-nCoV.pdf 